\title{
Rевеавсн Автісle: Individual level performance analysis of agricultural technology management agency in Assam
}

\author{
口 CHITTARANJAN DEKA, P. MISHRA AND R.K. TALUKDAR
}

Article Chronicle: Received : 02.06.2017;

Revised : 25.06.2017;

Accepted : 08.07.2017

KEY Words: ATMA, Governing body (GB), Functions/Activities, Role, Performance
SUMMARY : The agricultural technology management agency (ATMA) is a registered society of key stakeholders involved in agricultural activities for sustainable agricultural development in the district. It is a focal point for integrating research and extension activities and decentralizing day-to-day management of agricultural extension system. As the ATMA programme is under operation for the last ten years in Assam, the researchable questions may arise that to how and what extent the extension personnel (Members of ATMA Governing Body) from respective district performed their role to accomplish the functions/activities of ATMA. Keeping in view, a research study was carried out with the objectives i.e. 1. To assess role performance of members ATMA governing body, 2. To find out direct and indirect effects of a set of selected predictor variables on role performance of members of ATMA governing body. A multistage purposive cum random sampling method was followed for selection of the respondents of the study. The findings of the level of role performance of the GB members revealed that 80.00 per cent of the respondents had low to medium level of performance. Only 20.00 per cent of them were found with high level of role performance. The value of co-efficient of multiple regression $\left(\mathrm{R}^{2}\right)$ being 0.611 indicated that the independent variables viz., job satisfaction, achievement motivation, motivational profile, job value cherished, attitude towards extension work, organizational climate, leadership ability, role conflict and job stress jointly contributed 61.10 per cent towards the role performance of GB members. The $\mathrm{F}$ value $\left(\mathrm{F}=4.937^{* *}\right)$ was also found to be significant. The results of the path analyses that the variables leadership ability, job stress, motivational profile, achievement motivation, organizational climate and job satisfaction emerged to be six most important variables which exhibited substantial direct effects on the level of role performance of the GB members.

How to cite this article : Deka, Chittaranjan, Mishra, P. and Talukdar, R.K. (2017). Individual level performance analysis of agricultural technology management agency in Assam. Agric. Update, 12(3): 418-424; DOI : 10.15740/ HAS/AU/12.3/418-424.
Author for correspondence :

\section{CHITTARANJAN DEKA} Krishi Vigyan Kendra, BAKSA (ASSAM) INDIA Email:chittasarthebari@ gmail.com

See end of the article for authors' affiliations 